\title{
A history of struggle for now
}

\section{Benjamin Zephaniah}

We were trained by heavy music from the city

Our drum and bass caused empires to fall.

We took our blood and sweat and did graffiti

That's how we knew the writings on the wall.

We were trained by heavy rebels from the village

Who taught us how to write and burn with prose.

When invaders came to murder, rape and pillage

We danced the rebel dance and up we rose.

Tyrants came with killing machines

And bullets on their vests,

Women were held in quarantine

With vile virginity test.

Their vision was division,

Tearing families apart,

Their missiles had precision,

But we had honest art. 


\section{A history of struggle for now}

We were trained by women who carried the future

We were trained by children who were strong and wise.

The hostile environment called us the other,

But our truth and love was stronger than their lies.

We were trained by those who took poems to battle, Creatively we make our voices heard, Our interruptions make us owners of our struggles, We were taught to feel the power in the word. 